\title{
Study of clay minerals effect on curing characteristics of polymer blends and physical- mechanical properties of prepared vulcanizates
}

\author{
Beáta Pecušová ${ }^{1, *}$, Mariana Pajtášová ${ }^{1}$, Zuzana Mičicová ${ }^{1}$, Darina Ondrušová ${ }^{1}$, \\ Andrea Feriancová $^{1}$, Marcel Kohutiar ${ }^{1}$, Ivan Labaj ${ }^{1}$ \\ ${ }^{1}$ Department of Materials Technologies and Environment, Faculty of Industrial Technologies \\ in Puchov, Alexander Dubcek University of Trencin I. Krasku 491/30, 02001 Púchov, Slovakia
}

\begin{abstract}
The given paper deals with the study of the properties of clay minerals, namely montmorillonite and moreover, it is focused on effect of these clay minerals on the curing characteristics of the polymer blends and the physical-mechanical properties of prepared vulcanizates. Montmorillonite is a major clay mineral which has a wide application in many industrial branches. It belongs to the group of dioctahedral smectite minerals with structural type in the ratio of $2: 1$. Characteristics of prepared modified and organomodified clay minerals are based on sulphur vulcanisation accelerators which are used for the preparation of real polymer blend where they represent a partial replacement of the common carbon black filler and then, the effect on the curing characteristics of polymer blends as well as physicalmechanical properties of the prepared vulcanizates are investigated. The results exhibit that the clay-based filler (modified and organomodified clay minerals) can be used as a partial replacement while the quality of the prepared blends is preserved.
\end{abstract}

Keywords: clay minerals, montmorillonite, fillers, physical-mechanical properties, curing characteristics

\section{Introduction}

Clay minerals are hydrated silicates (hydro-silicates) with a layered structure. Montmorillonite (MMT) is the typical and important representative of the mentioned clay minerals. Montmorillonite belongs to the group of dioctahedral smectite minerals with the expanding structure. Particular interest in montmorillonite results from the fact that it has the ability to expand and absorb large organic molecules through its ion exchange reactions as well as other types of layered silicates. In addition to increasing the size of the interspaces, the character of the filler surface is changed from hydrophilic to hydrophobic (organophilic) [1]. The three-layered structure of MMT is the basic structural unit, which consists of two continuous tetrahedral networks and one octahedral network is placed between two tetrahedral networks. In relation to the structure, the significant substitution can be observed and it means that there is strong negative charge of the layer and this

\footnotetext{
*Corresponding author: beata.pecusova@,fpt.tnuni.sk
}

Reviewers: František Nový, Eva Tillová 
charge is compensated by the presence of exchangeable cations $\left(\mathrm{Na}^{+}, \mathrm{K}^{+}, \mathrm{Ca}^{2+}, \mathrm{Mg}^{2+}\right)$ in the interlayer [2]. Due to their properties, the given clays and clay minerals are applied in many industries - petroleum and cement industry. Moreover, they are also used for the production of animal feedstuffs, foodstuff, paper, rubber, plastics, synthetic leather, external and internal coverings, pencils, pastel colours, porcelain, heavy clay and fine ceramic products. In tread rubber blends, the clay minerals lead to tire adhesion improvement to wet road and better adhesion of rubber to steel cords. Clays and clay minerals are commonly used as a partial replacement of the carbon black representing the filler into rubber blends in order to reduce the prices of products as well as to make these products to be eco-friendly $[3,4,5]$.

\section{Material and methods}

\subsection{Preparation of modified and organomodified clay minerals}

Natural bentonite was crushed in a mortar and then, it was sieved out through a sieve, where the size of hole was $0.040 \mathrm{~mm}$ in diameter. Natural bentonite can be mainly found in the calcium form of MMT or in the sodium-calcium form of MMT and therefore, the calcium form of MMT was prepared from the calcium chloride solution. Undesirable salts were eliminated by help distilled water until the reaction with the silver nitrate solution exhibited negative presence of chloride anions. Using the calcium form of MMT and the mentioned procedures hereinbefore, further modified form of $\mathrm{Co}^{2+}$ ions was prepared from the solution of cobalt chloride. For the preparation the of organomodified clay mineral forms, organic blends based on dithiophosphate (V) and benzothiazole (B) were used as accelerators of sulphur curing in the rubber industry and these organic blends we prepared by saturation of the accelerator in gas state into the interlayer of modified clay minerals. All testing steps and procedures were carried out at the workplace of Faculty of Industrial Technologies in Puchov.

\subsection{Preparation of tread rubber blends}

The tread rubber blends were prepared by a two-step stirring of two types of the rubber while these two types of the rubber were subsequently stirred with the other ingredients and the process of stirring was carried out by help of Brabender Plastograph - the laboratory stirring machine where the volume of chamber was $70 \mathrm{~cm}^{3}$ and a stirrer speed was 50 $\mathrm{rev} / \mathrm{min}$. It is important to point out that the given stirring process was performed according to standards [6]. After the stirring process, the prepared blends were investigated from the aspect of the curing characteristics, using the Monsanto 100 Vulcameter. The given testing process was based on standardized procedures at temperature of $150{ }^{\circ} \mathrm{C}$ and the recording of time for curing curves was 60 minutes according to standards [7]. The physicalmechanical properties of vulcanizates were measured by help of Instron (tearing machine) at a laboratory temperature of $25^{\circ} \mathrm{C}$ and the deformation velocity was $50 \mathrm{~mm} / \mathrm{min}$, while it was in accordance with predetermined standards [8]. The hardness of the vulcanizates was measured by the IRHD hardness tester at temperature $23 \pm 2{ }^{\circ} \mathrm{C}$ and $6 \mathrm{~mm}$ test samples thickness [9]. All testing steps and procedures were carried out at the workplace of Faculty of Industrial Technologies in Puchov. Designation of tread rubber blends is shown in (Table 1). 
Table 1. Designation of tread rubber blends

\begin{tabular}{|c|c|c|}
\hline \multicolumn{2}{|c|}{ Designation of tread rubber blends } \\
\hline designation & filler & phr \\
\hline LB R & carbon black - N 339 & 87 \\
\hline LB 1 & MMT Ca & 0.5 \\
\hline LB 2 & MMT Ca & 1 \\
\hline LB 3 & MMT Ca & 1.5 \\
\hline LB 4 & MMT Ca-V & 0.5 \\
\hline LB 5 & MMT Ca-V & 1 \\
\hline LB 6 & MMT Ca-V & 1.5 \\
\hline LB 7 & MMT Ca-B & 0.5 \\
\hline LB 8 & MMT Ca-B & 1 \\
\hline LB 9 & MMT Ca-B & 1.5 \\
\hline LB 10 & MMT Co & 0.5 \\
\hline LB 11 & MMT Co & 1 \\
\hline LB 12 & MMT Co & 1.5 \\
\hline LB 13 & MMT Co-V & 0.5 \\
\hline LB 14 & MMT Co-V & 1 \\
\hline LB 15 & MMT Co-V & 1.5 \\
\hline LB 16 & MMT Co-B & 0.5 \\
\hline LB 17 & MMT Co-B & 1 \\
\hline LB18 & phr - per hundred rubber, filler amount in blend \\
\hline
\end{tabular}

\section{Results and discussion}

\subsection{Curing characteristics of tread rubber blends}

Curing characteristics of tread rubber blends are investigated on the basis of rheological records of curing curves relating to given blends. The evaluation of the curing characteristics was carried out for: minimum torque $\left(M_{L}\right)$, the maximum torque $\left(M_{H}\right)$, safety of rubber blends $\left(t_{s}\right)$, optimal time of vulcanization $\left(t_{C 90}\right)$ and velocity coefficient of vulcanization $\left(\mathrm{R}_{\mathrm{v}}\right)$. The measured values of the $M_{L}$ (Fig. 1) for the LB 1 - LB 6 tread rubber blends are almost comparable to the reference tread rubber blend (R), except for the LB 5 blend containing the MMT Ca-V filler in amount of $1 \mathrm{phr}$, because in this case, the value is higher. Values of the $M_{L}$ for LB 7 - LB 9 rubber blends with MMT Ca-B filler were higher, compared to R. In LB 10 - LB 18 blends, the $M_{L}$ values were almost comparable to R, except for LB 12 containing MMT Co filler and LB 15 containing MMT Co-V filler where the amount of given filler was $1.5 \mathrm{phr}$ for both cases. Containing the MMT Co-B filler, LB

16 blend (filler in the amount of $0.5 \mathrm{phr}$ ) and LB 18 blend (filler in the amount of $1.5 \mathrm{phr}$ ) 
indicate the higher stiffness of the sample at the beginning of curing process as well as higher viscosity in comparison with $\mathrm{R}$.

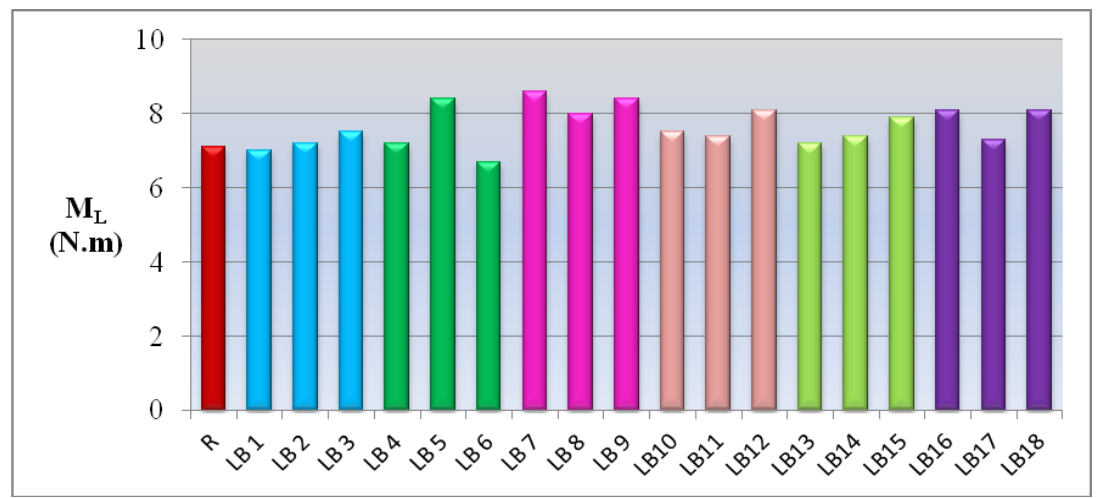

Fig. 1. Minimum torque of tread rubber blends

The values of the $M_{H}$ (Fig. 2) for almost all tread rubber blends are comparable to $\mathrm{R}$ value, except for LB 7, LB 9, LB 16, LB 17 blends, where $M_{H}$ values are higher. Lower $M_{H}$ values were measured for LB 1 - LB 3, LB 6, LB 10, LB 13, LB 14 blends and it indicates a lower stiffness and the viscosity of the blends at the end of the curing process.

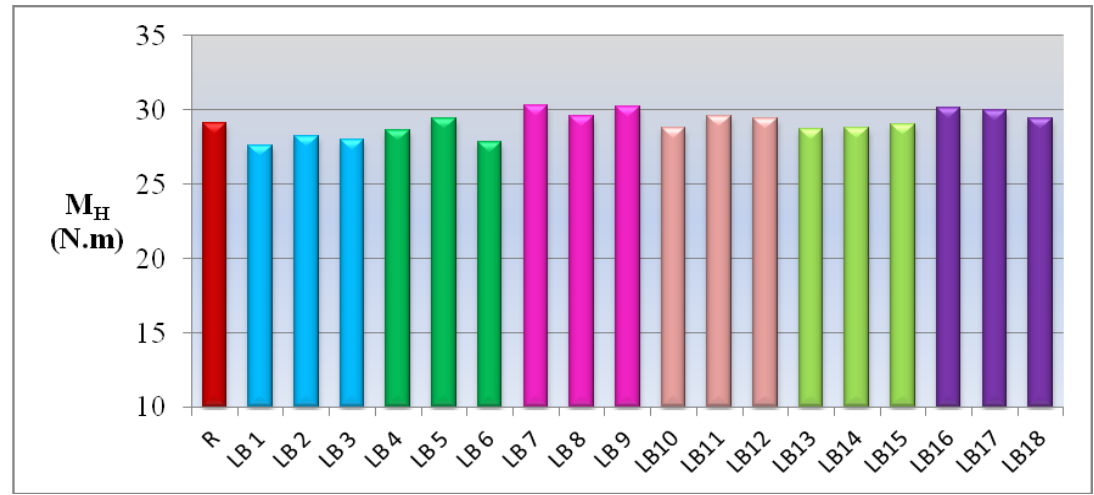

Fig. 2. Maximum torque of tread rubber blends

The $t_{s}$ values (Fig. 3) were higher in the case of LB 1 tread rubber blend containing the MMT Ca filler in the amount of 0.5 phr and LB 2 with a content of MMT Ca filler of $1 \mathrm{phr}$, compared to the reference tread rubber blend. This mentioned phenomenon can positively influence the processing properties of the blends and the physical-mechanical properties of the resultant vulcanizates. For the other blends, the $t_{s}$ values were lower in comparison with R. 


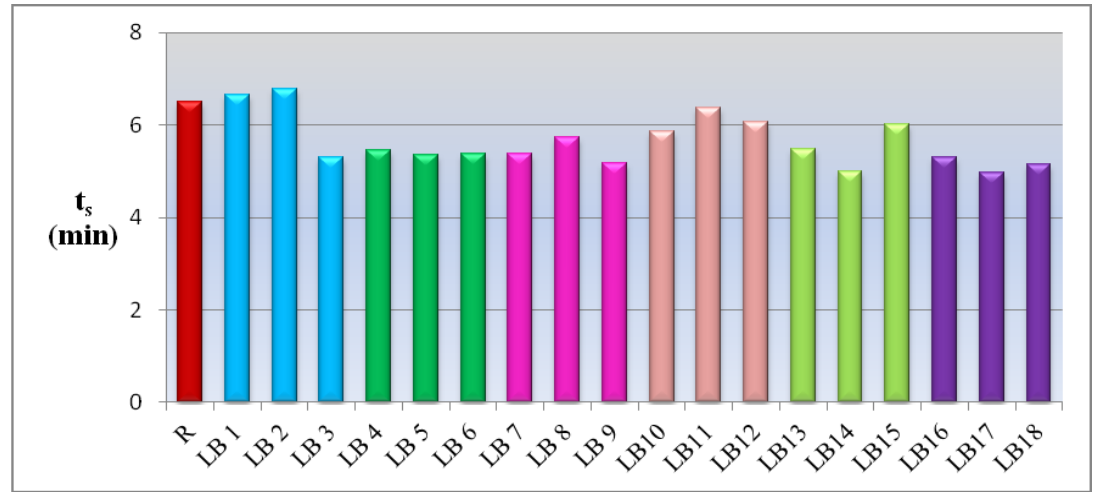

Fig. 3. Safety of tread rubber blends

The $t_{c 90}$ values (Fig. 4) are lower for the LB 4, LB 6, LB 7, LB 9, LB 10, LB 13, LB 14, LB 16 - LB 18 rubber blends in comparison with $\mathrm{R}$ and it has a beneficial effect on the curing process. Values of LB 3 containing MMT Ca, LB 5 containing MMT Ca-V and LB 8 containing the MMT Ca-B filler are comparable to the $t_{c 90}$ values of R.

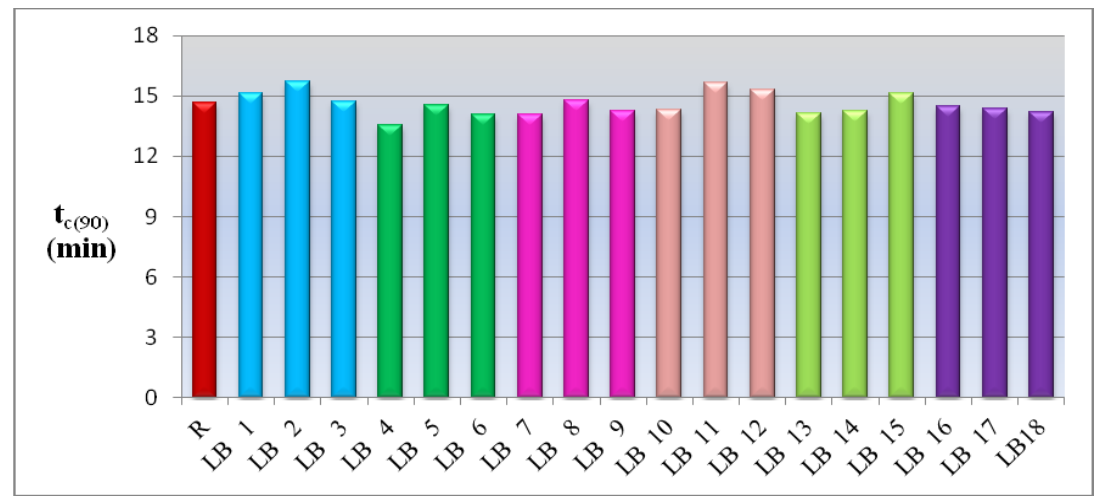

Fig. 4. Optimal time of tread rubber blends curing process

The results of velocity coefficient of curing process $\left(R_{v}\right)$ are shown graphically in Fig. 5 . The LB 4 tread rubber blend containing the MMT Ca-V filler in the amount of $0.5 \mathrm{phr}$ has a higher value of $R_{v}$ of curing process in comparison with $\mathrm{R}$ standing for reference blend and it leads to the higher the activity of the components of the rubber blend. LB 6 containing MMT Ca-V filler, LB 7 containing MMT Ca-B, LB 10 containing MMT Co and LB 13 containing MMT Co-V are comparable to R. In relation to the other investigated blends, they show lower values resulting in lower activity of the components. 


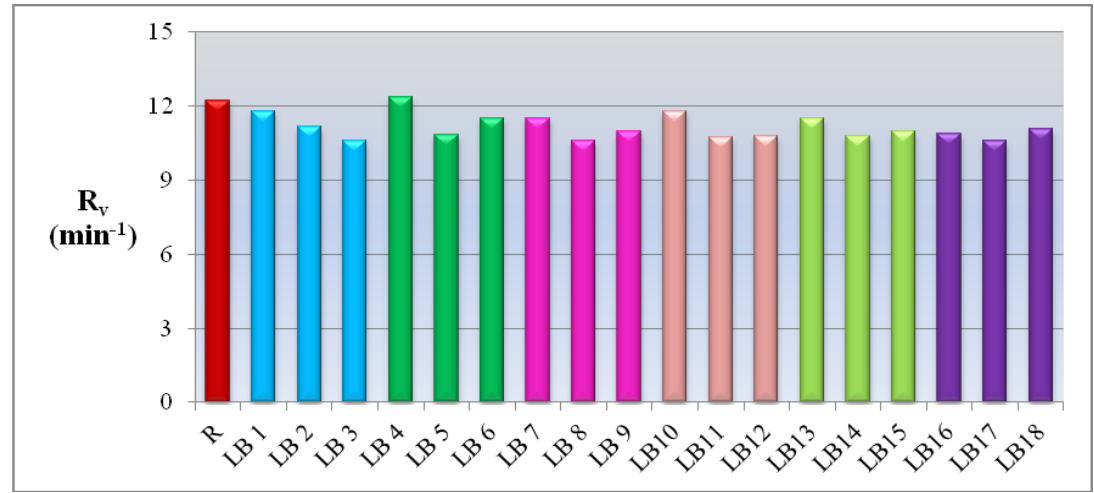

Fig. 5. Velocity coefficient of tread rubber blends curing

\subsection{Physical-mechanical properties of tread rubber blends}

Prepared tread vulcanizates in the form of test samples were used to determine the resulting physical-mechanical properties. The results for the reference vulcanizate $(\mathrm{R})$ and for the tread vulcanizates (LB 1 - LB 18) are graphically depicted (Fig. 6 - 8). For LB 2 tread rubber vulcanizate containing MMT $\mathrm{Ca}$, LB 5 vulcanizate containing MMT Ca-V, LB 8 vulcanizate containing MMT Ca-B in the amount of $1 \mathrm{phr}$, the tensile strength values were comparable to the reference vulcanizate. The other vulcanizates exhibit lower strength values, compared with reference vulcanizate. This is probably related to weaker interaction and bond between clay mineral filler particles and rubber matrix.

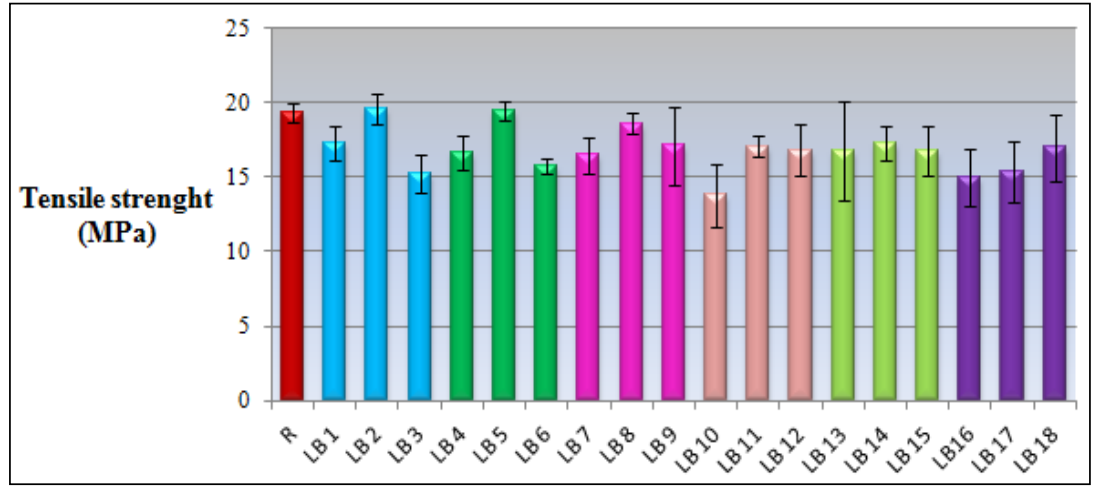

Fig. 6. Tensile strength of tread vulcanizates

In the case of the evaluation of the resulting tensibility (Fig. 7), it is observed that almost all of the prepared tread vulcanizates exhibit lower values in comparison with the reference vulcanizate, except for LB 1, LB 2, LB 5, LB 8 LB 13 and LB 14 blends, because these mentioned blends exhibit higher values of resulting tensibility. The LB 2 vulcanizate containing MMT Ca filler, LB 5 containing MMT Ca-V filler, LB 8 containing MMT Ca-B filler in the amount of $1 \mathrm{phr}$ have the highest values of the resulting tensibility and it leads to indication of a higher elasticity. 


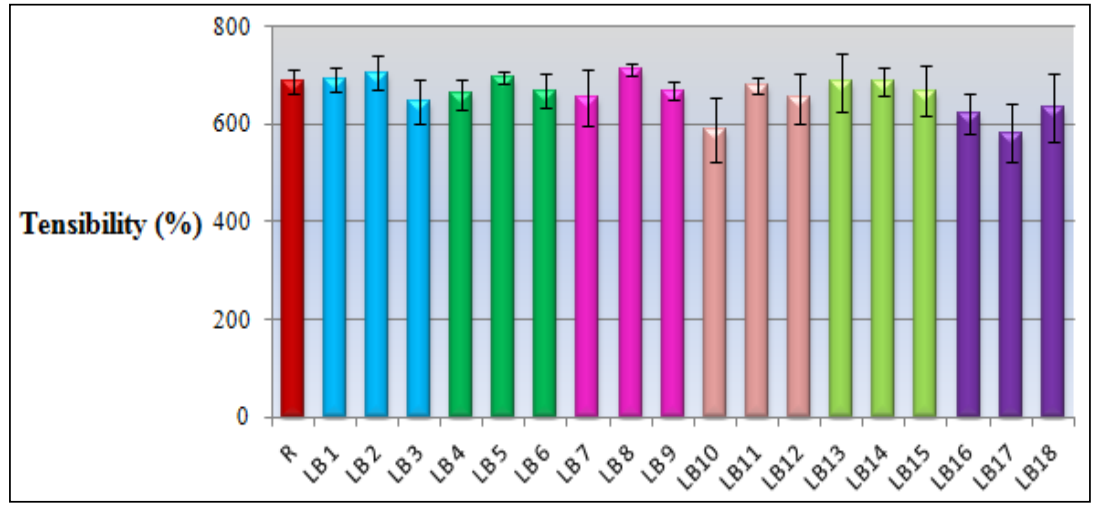

Fig. 7. Tensibility of tread vulcanizates

In relation to the hardness values of the resultant tread vulcanizates (Fig. 8), the given values are comparable to the reference vulcanizates value. Compared with the reference vulcanizate, the lowest hardness values were measured in the case of LB 6 tread vulcanizate containing MMT Ca-V filler in the amount of $1.5 \mathrm{phr}$ and LB 7 containing MMT Ca-B filler in the amount of $0.5 \mathrm{phr}$ and it is connected with a good incorporation of the filler into the blends and its good compatibility with the rubber matrix.

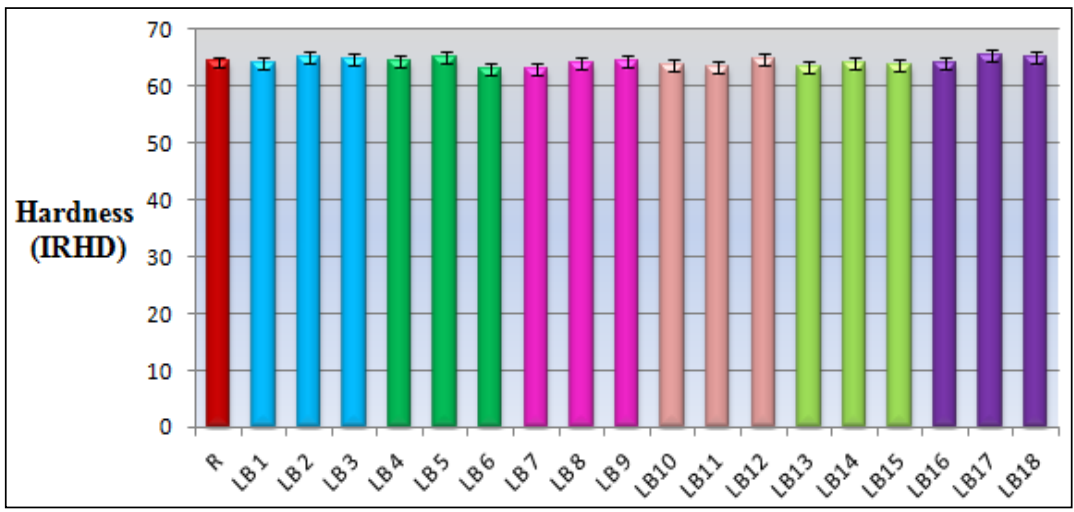

Fig. 8 Hardness of tread vulcanizates

\section{Conclusion}

The paper deals with the study of the effect of prepared modified and organomodified forms of MMT clay mineral filler on the properties of tread rubber blends. The investigation process involved the preparation of 19 tread rubber blends, while the filler in 18 blends was based on combination of specified amount of carbon black with clay. The reference sample represented the commonly used tread rubber blend in rubber industry, where the N 339 carbon black is filler. The given reference blend was used for comparison of specific curing characteristics leading to evaluation of the blend function. The evaluation of the curing characteristics was carried out for: minimum torque $\left(M_{L}\right)$, the maximum torque $\left(M_{H}\right)$, safety of rubber blends $\left(t_{s}\right)$, optimal time of vulcanization $\left(t_{C 90}\right)$ and velocity coefficient of vulcanization $\left(\mathrm{R}_{\mathrm{v}}\right)$.

In the form of double-sided blades, the resulting vulcanizates containing the filler based on combination of carbon black with clay were evaluated from the aspect of physical- 
mechanical properties (tensile strength, tensibility, hardness) and it was in accordance with valid standards. During the evaluation, the prepared samples were compared with the reference sample in order to specify the further application of the modified and organomodified clay mineral, especially MMT, in rubber industry. The obtained values indicate that fillers containing organomodified clay minerals with an intercalated accelerator on the basis of dithiophosphate (V) have higher influence on acceleration of the curing process in comparison with the fillers containing organomodified clay minerals with an intercalated accelerator on the basis of benzothiazole (B).

Acknowledgments: KEGA 007TnUAD-4/2017, VEGA grant No. 1/0649/17, VEGA grant No. 1/0589/17, project "Center for quality testing and diagnostics of materials", ITMS code 26210120046 relating to the Operational Program Research and Development, EF of Reg. Development.

\section{References}

1. V. Šucha, Íly v geologických procesoch. (Univerzita Komenského v Bratislave, Bratislava, 159 p., ISBN 80-223-1547- 8, 2001)

2. B. Číčel, I. Novák, I. Horváth, Mineralógia a kryštalochémia ílov. (Veda, Bratislava, Vydavatel'stvo SAV, Slovenská akadémia vied, 1981)

3. M. Badík, et al., Správa o stave životného prostredia žilinského kraja. (Slovenská agentúra životného prostredia Banská Bystrica, Žilina, 6 p., 1999)

4. J. Paliesková, M. Pajtášová, A. Feriancová, D. Ondrušová, K. Holcová, J. Vavro, Thermal properties of fillers based on organoclays in the polymeric materials. Journal of thermal analysis and calorimetry, 119 (2), 939-943 (2015)

5. D. Ondrušová, M. Pajtášová, Rubber components and their influence on rubber properties and environmental aspects of production. (Spolok Slovákov v Pol'sku, Krakow, 166 p., ISBN 978-83-7490-385-1, 2011)

6. STN 621425 Príprava behún̆ových gumárenských zmesí.

7. STN 621416 Stanovenie vulkanizačných charakteristik na vulkametri.

8. STN 621436 Stanovenie t'ahových vlastností.

9. STN 621433 Stanovenie tvrdosti vtláčaním hrotu tvrdomera IRHD. 